\title{
Dairy cows feeding with sorghum silage supplemented with concentrate ${ }^{1}$
}

\author{
Joabe Jobson de Oliveira Pimentel ${ }^{2}$, Rogério de Paula Lana ${ }^{3}$, \\ André Soares de Oliveira ${ }^{4}$, Rafael Monteiro Araújo Teixeira ${ }^{5}$, Daniel Carneiro de Abreu ${ }^{3}$
}

\begin{abstract}
RESUMO
Alimentação de vacas leiteiras

com silagem de sorgo suplementada com concentrado

Alimentos concentrados podem ser utilizados para aumentar a produção de leite, em fazendas leiteiras. No entanto, o custo com alimentação aumenta, quando concentrados são utilizados, e, algumas vezes, os produtores perdem competitividade, se as vacas não produzirem o que é esperado com a suplementação. Neste sentido, este trabalho objetivou avaliar o consumo de nutrientes, produção e composição de leite e mudança no peso corporal de vacas leiteiras recebendo silagem de sorgo sem ou com suplementação com concentrados. Nove vacas cruzadas (Holandês-Gir) foram alocadas em três quadrados latinos balanceados e alimentadas com silagem de sorgo suplementada com minerais $(0,2 \mathrm{~kg})$ ou com $2,6 \mathrm{~kg}$ (38,5\% de proteína bruta) ou 5,0 $\mathrm{kg}$ ( $20 \%$ de proteína bruta) de concentrado por dia, com vistas a suprir a mesma quantidade de proteína bruta $\left(1,0 \mathrm{~kg} \mathrm{dia}^{-1}\right)$. O consumo de matéria seca e a produção de leite foram maiores para as vacas alimentadas com concentrado, independentemente do nível de proteína. A resposta produtiva $(\mathrm{kg}$ de leite por kg de concentrado) foi de 1,67 e 0,83, para o baixo e alto nível de suplementação, respectivamente. Vacas que receberam somente minerais perderam peso, enquanto aquelas que consumiram concentrados ganharam peso. Vacas que produziram $13,0 \mathrm{~kg}$ de leite dia $^{-1}$ apresentaram maior aumento na produção quando alimentadas com suplemento contendo altos teores de proteína e mistura mineral. A resposta na produção de leite por $\mathrm{kg}$ de concentrado foi maior, quando menor quantidade de concentrado com altos níveis de proteína e minerais foi utilizada, permitindo redução nos custos de produção.
\end{abstract}

PALAVRAS-CHAVE: Leite; consumo de nutrientes; custos de produção.

\section{INTRODUCTION}

During the dry season, the reduction in pasture quantity and quality make necessary the use of

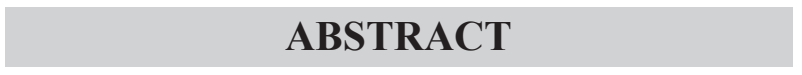

Concentrated feed can be used to increase the milk yield in dairy farms. However, the feeding cost increases when concentrates are used and, sometimes, farmers lose competitiveness, if the cows do not produce what is expected with supplementation. Thus, this study aimed at evaluating the nutrients intake, milk yield and composition and live weight change of dairy cows fed with sorghum silage alone or supplemented with concentrates. Nine crossbred cows (Holstein-Gyr) were allocated in three balanced Latin squares and fed with sorghum silage supplemented with minerals $(0.2 \mathrm{~kg})$ or with $2.6 \mathrm{~kg}$ (38.5\% of crude protein) or $5.0 \mathrm{~kg}(20 \%$ of crude protein) of concentrate per day, aiming at supplying the same amount of crude protein $\left(1.0 \mathrm{~kg} \mathrm{day}^{-1}\right)$. The dry matter intake and milk yield were higher for the cows fed with concentrate, independently of its protein level. The productive response (in $\mathrm{kg}$ of milk per $\mathrm{kg}$ of concentrate) was 1.67 and 0.83 , respectively for the low and high supplemental levels. The cows that received only minerals lost weight, while those fed with concentrate gained weight. The cows which produced $13.0 \mathrm{~kg}$ of milk day ${ }^{-1}$ showed a higher increase in milk yield when fed with supplements containing high protein and mineral contents. The response for milk production per kg of concentrate was higher when lower amounts of concentrate with high protein and mineral levels were used, allowing a reduction in the production costs.

KEY-WORDS: Milk; nutrients intake; production costs.

ensiled forages for dairy cows. The importance of sorghum silage has increased yearly, due to its high tolerance to hydric stress (Souza et al. 2003, Macedo et al. 2012).

1. Article received in Sep./2012 and accepted for publication in Jul./2013 (Registration number: PAT 20320).

2. Instituto Federal de Educação, Ciência e Tecnologia Baiano (IFBA), Teixeira de Freitas, BA, Brasil.

E-mail: jobsonpimentel@yahoo.com.br.

3. Universidade Federal de Viçosa (UFV), Centro de Ciências Agrárias, Departamento de Zootecnia, Viçosa, MG, Brasil. E-mails: rlana@ufv.br, daniel.abreu@ufv.br.

4. Universidade Federal de Mato Grosso (UFMT), Centro de Ciências Agrárias e Ambientais, Sinop, MT, Brasil. E-mail: andresoli@ufmt.br.

5. Instituto Federal de Educação, Ciência e Tecnologia do Triângulo Mineiro (IFTM), Uberaba, MG, Brasil. E-mail: rafaelaldeia@yahoo.com.br. 
Although presenting reasonable energy content, the sorghum silage has lower crude protein than it would be required for a good productive performance of dairy cows. Thus, the protein supplementation of sorghum silage with concentrates improves significantly the dry matter intake and the digestibility coefficients of nutrients (Pimentel et al. 1998).

The use of concentrates is fundamental to increase milk production. However, their use decreases linearly the milk yield with the increase in the amount supplied (Lana 2009, Silva et al. 2009, Oliveira et al. 2011, Teixeira et al. 2011). Moreover, the ingredients that compose the concentrate are expensive, raising the feeding costs (Lana 2005, Lana et al. 2005, Vilela et al. 2006, Pimentel et al. 2011). Therefore, a balanced supply of concentrates is fundamental to attain economic viability of supplementation.

More than $90 \%$ of the concentrates supplied for dairy cows, in Brazil, contain about $20-22 \%$ of crude protein. It is recommended to supply $1.0 \mathrm{~kg}$ of ration for each $3.0 \mathrm{~kg}$ of milk. By following this recommendation and considering an average milk yield of 15.0-20.0 kg day ${ }^{-1}$, the requirements in crude protein (CP) are fulfilled, but an excess of energy is being supplied (AFRC 1993, NRC 2001, Lana 2005).

The use of lower amounts of concentrate to produce the same amount of milk would support a greater economy to the milking systems, leading to a larger number of producers to adopt the supplement routinely in their farms, especially the ones located far from large consumption centers.

This study aimed at evaluating the effect of the reduction in the amount of supplied concentrates for dairy cows, maintaining the same amount of supplied protein and minerals by increasing their contents in the concentrate, and meeting the protein and mineral requirements of the animals, in order to decrease production costs.

\section{MATERIAL AND METHODS}

The experiment was performed in the Instituto Federal de Educação, Ciência e Tecnologia, in Januária, north of the Minas Gerais State, Brazil, from August 28th to October 8th, 2009, under farm conditions. The procedures meet the norms of the ethical and animal welfare committees of the Universidade Federal de Viçosa, Minas Gerais State, Brazil.
Nine multiparous crossbred Holstein-Gyr cows (1/4 to $3 / 4$ European grade) of $512 \pm 38.56 \mathrm{~kg}$ live weight (LW) were used, with milk production potential from 4,500 to $6,000 \mathrm{~kg}$ per lactation, presenting an average production of $12.0 \mathrm{~kg}$ of milk day $^{-1}$, at the beginning of the experimental period, and averaging 127 and 179 days in milk, respectively at the beginning and end of the experiment. The cows were distributed in three $3 \times 3$ Latin squares, balanced in accordance with the milk yield, at the beginning of the experiment.

The experiment was conducted in 52 days, being 10 days for adaptation to the experimental conditions and three periods with 14 days each for the measurements. Each measuring period consisted of ten days for adaptation to the experimental diets and four days for data and sample collection.

Treatments consisted of a control (200.0 $\mathrm{g}$ of mineral mixture supplementation $\mathrm{cow}^{-1} \mathrm{day}^{-1}$ ) and two treatments containing concentrate with $38.5 \%$ and $20 \%$ of crude protein, respectively in the amounts of $2.6 \mathrm{~kg} \mathrm{cow}^{-1}$ day $^{-1}$ and $5.0 \mathrm{~kg} \mathrm{cow}^{-1}$ day $^{-1}$, to offer $1.0 \mathrm{~kg}$ of crude protein per animal per day, in both treatments. The concentrate with high protein (HP) level was formulated using only soybean meal and mineral premix, while the one with low protein (LP) content was formulated with cracked corn, soybean meal and mineral premix, in accordance with the recommendation of the manufacturer, to obtain $20 \%$ of crude protein. The mineral supplement was the same and equally distributed in the same amount $\left(\mathrm{g} \mathrm{day}^{-1}\right)$ for all cows in the three treatments.

The animals were maintained in individual stalls and received sorghum silage plus supplementation treatments (Table 1). Feed was supplied twice a day, at 8 a.m. and 5 p.m., just after milking, as total diet. The amount offered was enough to allow orts between $5 \%$ and $10 \%$ of the total offered.

Cows were mechanically milked twice daily, at 6 a.m. and 2 p.m., making up the daily record of milk production, during the last seven days of each experimental period. Milk samples were collected on the 14th day, at the morning and afternoon milking, and pooled to obtain approximately $100.0 \mathrm{~mL}$ for analysis of crude protein, fat, lactose and total dry extract. The milk samples were analyzed at the Embrapa Gado de Leite, in Juiz de Fora, Minas Gerais State, Brazil.

Samples of offered feed and orts were collected in the last four days of each experimental period and 
Table 1. Ratio of the ingredients used in the composition of supplements (Januária, MG, 2009).

\begin{tabular}{lcccrrr}
\hline \multirow{2}{*}{ Ingredient } & \multicolumn{4}{c}{ Treatment $^{1}$} \\
\cline { 2 - 7 } & \multicolumn{2}{c}{ Mineral mixture } & \multicolumn{2}{c}{ High protein } & \multicolumn{2}{c}{ Low protein } \\
\cline { 2 - 7 } & $\mathrm{kg} \mathrm{day}^{-1}$ & $\%$ & $\mathrm{~kg} \mathrm{day}^{-1}$ & $\%$ & $\mathrm{~kg} \mathrm{day}^{-1}$ & $\%$ \\
\hline Cracked corn & - & - & - & - & 3.2 & 64 \\
Soybean meal & - & - & 2.4 & 92 & 1.6 & 32 \\
Mineral mixture & 0.2 & 100 & 0.2 & 8 & 0.2 & 4 \\
\hline Total & 0.2 & 100 & 2.6 & 100 & 5.0 & 100 \\
\hline
\end{tabular}

${ }^{1}$ Guarantee levels $\left(\mathrm{kg}^{-1}\right): \mathrm{Ca}=230 \mathrm{~g} ; \mathrm{P}=90 \mathrm{~g} ; \mathrm{S}=15 \mathrm{~g} ; \mathrm{Mg}=20 \mathrm{~g} ; \mathrm{Na}=48 \mathrm{~g} ; \mathrm{Co}=100 \mathrm{mg} ; \mathrm{Cu}=700 \mathrm{mg} ; \mathrm{Fe}=2,000 \mathrm{mg} ; \mathrm{I}=80 \mathrm{mg} ; \mathrm{Mn}=1,250 \mathrm{mg} ; \mathrm{Se}=20 \mathrm{mg}$; $\mathrm{Zn}=2,700 \mathrm{mg} ; \mathrm{F}=900 \mathrm{mg}$; Vitamin A = 200,000 UI; Vitamin D3 = 60,000 UI; Vitamin E = 60 UI.

frozen at $-20^{\circ} \mathrm{C}$, for later analyses and estimates of nutrient intake.

The $3.5 \%$ fat corrected milk (FCM) was calculated according to Sklan et al. (1992), using the equation: $\mathrm{FCM}=(0.432+0.1625 \mathrm{x} \%$ fat of milk $) \mathrm{x}$ milk production, in $\mathrm{kg} \mathrm{day}^{-1}$.

At the beginning and end of each experimental period, cows were weighed for evaluation of the changes in the live weight. The weights of the animals corresponded to the average of two daily weights (morning and afternoon) carried out soon after milking and before feeding the experimental diets.

Feed and orts samples were then dried in a forced $60^{\circ} \mathrm{C}$ drying oven, for 72 hours, and ground with a hammer mill (Willey mill grinder produced by Arthur H. Thomas, Philadelphia, PA) to pass a $2.0 \mathrm{~mm}$ screen. Sample preparation (feed, orts) and the analysis of dry matter (DM), organic matter (OM), mineral matter (MM), nitrogen compounds $(\mathrm{N})$, ether extract (EE), neutral detergent fiber (NDF) and acid detergent fiber (ADF) were performed according to Silva \& Queiroz (2002). The NDF and ADF were analyzed without sodium sulphite and values were not corrected for residual ash. The contents of total carbohydrates $(\mathrm{CHO})$ were calculated as
$\% \mathrm{CHO}=100-(\% \mathrm{CP}+\% \mathrm{EE}+\% \mathrm{MM})$, according to Sniffen et al. (1992). The analyses of variance were performed considering the three $3 \times 3$ Latin squares design, including effects of treatment (by orthogonal contrasts), animals inside the Latin square and period, assuming a probability of $5 \%$.

\section{RESULTS AND DISCUSSION}

The sorghum silage composition presented similar values to that observed by Valadares Filho et al. (2006), except for the crude protein, whose value was higher (Table 2), although it was inside the confidence interval.

Souza et al. (2003), studying the nutritional value of five sorghum varieties, found lower values for crude protein and neutral detergent fiber and higher values for dry matter, ether extract and total carbohydrates than the values found in the present study. The highest value for crude protein content verified in the sorghum silage of this study can be related to the presence of weed legumes that was evidenced in the harvest of the material for ensilage.

The MM and LP treatments presented crude protein content below $13.3 \%$ (Table 3 ), recommended

Table 2. Percentile composition of ingredients, concentrates and silages, by sampling periods (Januária, MG, 2009).

\begin{tabular}{lccrrrrrr}
\hline \multirow{2}{*}{ Item $^{2}$} & \multicolumn{2}{c}{ Ingredient } & \multicolumn{3}{c}{ Concentrate $^{1}$} & \multicolumn{3}{c}{ Silage (periods) } \\
\cline { 2 - 8 } & Corn & Soybean & MM & HP & LP & One & Two & Three \\
\hline DM & 92.1 & 93.9 & 97.5 & 94.2 & 92.9 & 29.3 & 32.4 & 29.6 \\
OM & 99.1 & 93.6 & 7.1 & 86.7 & 94.5 & 92.6 & 87.6 & 92.5 \\
TC & 85.5 & 41.5 & 0.0 & 38.1 & 67.7 & 82.0 & 78.1 & 82.7 \\
CP & 8.9 & 49.9 & 0.0 & 45.9 & 22.6 & 8.5 & 7.9 & 8.21 \\
EE & 4.7 & 2.2 & 0.0 & 2.0 & 3.7 & 2.2 & 1.71 & 1.6 \\
Ash & 0.9 & 6.7 & 92.9 & 13.3 & 5.5 & 7.4 & 12.4 & 7.5 \\
NDF & 14.8 & 15.4 & 0.0 & 14.1 & 14.5 & 73.7 & 83.7 & 77.6 \\
NSC & 70.7 & 26.1 & 0.0 & 24.0 & 53.2 & 8.3 & 4.4 & 5.1 \\
\hline
\end{tabular}

${ }^{1} \mathrm{MM}=$ mineral mixture; $\mathrm{HP}=$ high protein treatment; $\mathrm{LP}=$ low protein treatment. ${ }^{2} \mathrm{DM}=$ dry matter; $\mathrm{OM}=$ organic matter; $\mathrm{TC}=$ total carbohydrates; $\mathrm{CP}=$ crude protein; $\mathrm{EE}=$ ether extract; $\mathrm{NDF}=$ neutral detergent fiber; $\mathrm{NSC}=$ non structural carbohydrates. 
Table 3. Percentile composition of experimental diets (Januária, MG, 2009).

\begin{tabular}{|c|c|c|c|c|c|c|}
\hline \multirow{2}{*}{ Item $^{3}$} & \multicolumn{3}{|c|}{ Treatment $^{1}$} & \multicolumn{2}{|c|}{ P-value ${ }^{2}$} & \multirow{2}{*}{$\mathrm{SE}^{4}$} \\
\hline & MM & HP & LP & Concentrate & HP x LP & \\
\hline $\mathrm{DM}$ & 29.8 & 34.7 & 40.3 & 0.001 & 0.001 & 0.513 \\
\hline $\mathrm{OM}$ & 89.4 & 90.3 & 91.9 & 0.001 & 0.001 & 0.201 \\
\hline $\mathrm{TC}$ & 79.4 & 74.0 & 77.5 & 0.001 & 0.001 & 0.200 \\
\hline $\mathrm{CP}$ & 8.0 & 14.2 & 12.0 & 0.001 & 0.001 & 0.172 \\
\hline $\mathrm{EE}$ & 1.89 & 1.91 & 2.40 & 0.001 & 0.001 & 0.031 \\
\hline Ash & 10.6 & 9.7 & 8.1 & 0.001 & 0.001 & 0.201 \\
\hline NDF & 78.3 & 69.2 & 62.1 & 0.001 & 0.001 & 0.645 \\
\hline $\mathrm{NSC}$ & 1.1 & 4.8 & 15.4 & 0.001 & 0.001 & 0.583 \\
\hline
\end{tabular}

${ }^{1} \mathrm{MM}=$ mineral mixture; HP $=$ high protein; $\mathrm{LP}=$ low protein. ${ }^{2}$ Concentrate $=$ contrast HP and LP versus MM; HP x LP = contrast HP versus LP. ${ }^{3} \mathrm{DM}=\mathrm{dry}$ matter; $\mathrm{OM}=$ organic matter; $\mathrm{TC}=$ total carbohydrates; $\mathrm{CP}=$ crude protein; $\mathrm{EE}=$ ether extract; $\mathrm{NDF}=$ neutral detergent fiber; $\mathrm{NSC}=$ non structural carbohydrates ${ }^{4} \mathrm{SE}=$ standard error; degrees of freedom $=6$.

by Lana (2005) for the average weight and milk production observed in the experiment. In the HP treatment, the crude protein level of the diet was greater than the value calculated with the use of the related spread sheet. These results indicate an expected greater response in milk production to the concentrate of HP, when compared with the LP diet.

The dry matter intake and its constituents, except for silage intake, increased with concentrate supplements $(\mathrm{p}<0.05$; Table 4$)$. When analyzed the percentage of live weight, the dry matter intake and neutral detergent fiber also increased with concentrate supplements $(\mathrm{p}<0.05$; Table 4$)$. According to Mertens (1994), the dry matter intake is controlled by physical, physiological and psychogenic factors, following a quadratic model. The dry matter intake and its constituents increase (except for fiber, which can vary as stated ahead) as concentrate is added to the diet until the inflection point, as observed in this experiment, and then it starts to reduce, keeping the energy intake constant as a function of the genetic potential of the animal.

The measured silage dry matter intake did not differ among the three treatments $(\mathrm{p}>0.05)$. Therefore, silage dry matter intake was not replaced by concentrate supply. Pimentel et al. (1998) observed increased intake of sorghum silage, when supplemented with soybean meal in $20 \%$ of the dietary dry matter, and Mota et al. (2010) verified a decrease in silage intake, when concentrate supply increased 2.7-5.3 $\mathrm{kg} \mathrm{cow}^{-1}$ day $^{-1}$, in cows reared in coastcross pasture, during the rainy season. According to Moore et al. (1997), at low supplementation rates, changes in silage intake can be both positive and negative, but for high supplementation rates, changes are always negative. In addition, Moore et al. (1997) stated that there is no consistent relationship of changes between silage intake and supplement type.

Table 4. Nutrient intake according to each treatment (Januária, MG, 2009).

\begin{tabular}{|c|c|c|c|c|c|c|}
\hline \multirow{2}{*}{ Item $^{4}$} & \multicolumn{3}{|c|}{ Treatment $^{1}$} & \multicolumn{2}{|c|}{ P-value ${ }^{2}$} & \multirow{2}{*}{$\mathrm{SE}^{3}$} \\
\hline & MM & HP & LP & Concentrate & HP x LP & \\
\hline \multicolumn{7}{|c|}{ Nutrient intake $\left(\mathrm{kg}\right.$ day $\left.{ }^{-1}\right)$} \\
\hline $\mathrm{DM}$ & 11.9 & 15.5 & 17.4 & 0.001 & 0.086 & 0.597 \\
\hline FDM & 11.7 & 13.1 & 12.8 & ns & ns & 0.594 \\
\hline $\mathrm{OM}$ & 10.6 & 14.0 & 16.1 & 0.001 & 0.034 & 0.533 \\
\hline $\mathrm{TC}$ & 9.4 & 11.5 & 13.5 & 0.001 & 0.019 & 0.470 \\
\hline $\mathrm{CP}$ & 0.95 & 2.19 & 2.09 & 0.001 & ns & 0.051 \\
\hline $\mathrm{EE}$ & 0.23 & 0.30 & 0.42 & 0.001 & 0.001 & 0.014 \\
\hline Ash & 1.26 & 1.54 & 1.40 & 0.015 & ns & 0.066 \\
\hline DMI\%LW & 2.46 & 3.13 & 3.50 & 0.001 & 0.004 & 0.081 \\
\hline NDFI\%LW & 1.93 & 2.16 & 2.17 & 0.007 & ns & 0.064 \\
\hline
\end{tabular}

${ }^{1} \mathrm{MM}=$ mineral mixture; $\mathrm{HP}=$ high protein; $\mathrm{LP}=$ low protein. ${ }^{2}$ Concentrate $=$ contrast $\mathrm{HP}$ and LP versus MM; HP $\mathrm{x} \mathrm{LP}=$ contrast HP versus LP. ${ }^{3} \mathrm{SE}=\mathrm{standard}$ error; degrees of freedom $=6 .{ }^{4} \mathrm{DM}=$ dry matter; $\mathrm{FDM}=$ forage dry matter (estimated according to the intake equation by using the $\mathrm{NRC} 2001$ ); $\mathrm{OM}=$ organic matter; $\mathrm{TC}=$ total carbohydrates; $\mathrm{CP}=$ crude protein; $\mathrm{EE}=$ ether extract; $\mathrm{DMI} \% \mathrm{LW}=$ dry matter intake per live weight; NDFI\%LW = neutral detergent fiber insoluble per live weight. 
Dry matter and crude protein intakes increased with concentrate supplementation $(\mathrm{p}<0.05)$, but there was no difference between the two concentrates, for these variables (Table 4). The low protein content of the diet, when the silage was supplied as exclusive feed source, can partly explain the low dry matter intake observed (Pimentel et al. 1998).

Milford \& Minson (1965 apud Martin et al. 1981) affirmed that the intake of low quality grass apparently is limited by insufficient supplied nitrogen levels to the microorganisms of the rumen. In accordance with Fontaneli et al. (1996), the sorghum silage, due to its low protein content, can not possess sufficient degradable protein for adequate microbial growth, leading to low dry matter intake.

The milk production with and without fat correction were similar $(p>0.05)$ in the treatments with supplementation and higher $(p<0.05)$ than the one verified in the control treatment (Table 5), being consistent with the dry matter and crude protein intakes (Table 4). Freitas et al. (2006) found significant correlation between dry matter intake and milk production, in which greater dry matter intake and its constituents promoted greater supply of nutrients for milk production. The percentage of fat, protein, lactose and total dry extract did not differ $(p>0.05)$ among treatments.

For the high protein treatment $38.5 \%$ of $\mathrm{CP}$ ), the milk response (calculated as increased milk production divided by increased concentrate intake, in relation to the control mineral mixture treatment) was $1.67 \mathrm{~kg}$ of milk per $\mathrm{kg}$ of concentrate. This means twice the amount of milk obtained when the concentrate with $20 \%$ of crude protein was used (LP), being $0.83 \mathrm{~kg}$ of milk per $\mathrm{kg}$ of concentrate. According to Bargo et al. (2003), the productive response is higher in the initial levels of supplementation with concentrates, decreasing with the increase of the supplementation level.

The economic return of the supplements is directly related to the increase in milk production, with the inclusion of the concentrate in the diet. Production per $\mathrm{kg}$ of milk per $\mathrm{kg}$ of concentrate can be used as an indicator of economic viability of the supplementation, when considering the prices of the concentrate and milk.

According to Bargo et al. (2003), the higher the substitution rate of silage by concentrate, as observed in diets with high level of concentrate, lower is the productive response to the use of concentrates, which can compromise the economic efficiency of the supplementation. In the present study, the silage intake was the same for treatments with and without concentrates. Therefore, the substitution rate did not explain the lower productive response verified for the higher supplementation level. Another explanation can be found in Oliveira et al. (2011), which used

Table 5. Milk production and composition, milk response and live weight according to treatments (Januária, MG, 2009).

\begin{tabular}{|c|c|c|c|c|c|c|}
\hline \multirow{2}{*}{ Item $^{3}$} & \multicolumn{3}{|c|}{ Treatment $^{1}$} & \multicolumn{2}{|c|}{ P-value ${ }^{2}$} & \multirow{2}{*}{$\mathrm{SE}^{4}$} \\
\hline & MM & HP & LP & Concentrate & HP x LP & \\
\hline \multicolumn{7}{|c|}{ Milk production $(\mathrm{kg}$ day-1) } \\
\hline MP & 8.8 & 12.8 & 12.7 & 0.001 & ns & 0.561 \\
\hline FCM $3.5 \%$ & 8.5 & 13.2 & 12.8 & 0.001 & ns & 0.602 \\
\hline \multicolumn{7}{|c|}{ Milk composition (\%) } \\
\hline $\mathrm{EE}$ & 3.76 & 4.19 & 4.06 & 0.001 & 0.080 & 0.060 \\
\hline $\mathrm{CP}$ & 3.37 & 3.22 & 2.96 & 0.034 & ns & 0.100 \\
\hline LA & 4.48 & 4.36 & 4.24 & 0.016 & 0.051 & 0.057 \\
\hline TS & 12.6 & 12.8 & 12.3 & ns & 0.007 & 0.111 \\
\hline \multicolumn{7}{|c|}{ Milk response } \\
\hline M/DMI & 0.75 & 0.83 & 0.73 & ns & ns & 0.047 \\
\hline $\mathrm{M} / \mathrm{C}$ & & 1.67 & 0.83 & & 0.001 & 0.047 \\
\hline \multicolumn{7}{|c|}{ Live weight } \\
\hline LWinitial & 492 & 483 & 492 & ns & ns & 13.38 \\
\hline LWfinal & 482 & 497 & 500 & ns & ns & 12.77 \\
\hline LWchange & -0.587 & 0.992 & 0.627 & 0.001 & ns & 0.238 \\
\hline
\end{tabular}

${ }^{1} \mathrm{MM}=$ mineral mixture; $\mathrm{HP}=$ high protein; $\mathrm{LP}=$ low protein. ${ }^{2}$ Concentrate $=$ contrast $\mathrm{HP}$ and LP versus MM; HP x LP = contrast HP versus LP. ${ }^{3} \mathrm{MP}=$ milk production; $\mathrm{FCM}=$ fatty corrected milk $(3.5 \%$ of fat $) ; \mathrm{EE}=$ ether extract; $\mathrm{CP}=$ crude protein; $\mathrm{LA}=$ lactose; $\mathrm{TS}=$ total solids; $\mathrm{M} / \mathrm{DMI}=\mathrm{kg}$ of milk per kg of dry matter intake; $\mathrm{M} / \mathrm{C}=\mathrm{kg}$ of milk per $\mathrm{kg}$ of concentrate; $\mathrm{LW}=$ live weight $(\mathrm{kg}) .{ }^{4} \mathrm{SE}=$ standard error; degrees of freedom $=6$. 
Table 6. Cost of ingested diets, simulated income and partial profit, in R $\$$ cow $^{-1}$ day $^{-1}$ (Januária, MG, 2009).

\begin{tabular}{|c|c|c|c|c|c|c|}
\hline \multirow{2}{*}{ Item } & \multicolumn{3}{|c|}{ Treatment $^{1}$} & \multicolumn{2}{|c|}{$\mathrm{P}$-value ${ }^{2}$} & \multirow{2}{*}{$\mathrm{SE}^{8}$} \\
\hline & MM & HP & LP & Concentrate & HP x LP & \\
\hline \multicolumn{7}{|c|}{ Feeding cost } \\
\hline $\operatorname{cosTf}^{3}$ & 3.39 & 5.58 & 6.35 & 0.001 & 0.001 & 0.127 \\
\hline INCM- $60^{4}$ & 5.28 & 7.71 & 7.60 & 0.001 & ns & 0.338 \\
\hline PPf- $60^{5}$ & 1.89 & 2.13 & 1.25 & $\mathrm{~ns}$ & $\mathrm{~ns}$ & 0.328 \\
\hline INCM-776 & 6.78 & 9.00 & 9.76 & 0.001 & ns & 0.434 \\
\hline PPf- $77^{7}$ & 3.38 & 4.31 & 3.41 & $\mathrm{~ns}$ & ns & 0.419 \\
\hline
\end{tabular}

$\mathrm{MM}=$ mineral mixture; HP = high protein; LP $=$ low protein. ${ }^{2}$ Concentrate $=$ contrast HP and LP versus MM; HP x LP $=$ contrast HP versus LP. ${ }^{3}$ Cost of consumed diets. ${ }^{4}$ Daily income with milk at $\mathrm{R} \$ 0.60 .{ }^{5}$ Partial profit with milk at $\mathrm{R} \$ 0.60 .{ }^{6}$ Daily income with milk at $\mathrm{R} \$ 0.77 .{ }^{7}$ Partial profit with milk at $\mathrm{R} \$ 0.77 .{ }^{8} \mathrm{SE}=$ standard error; degrees of freedom $=6$.

the saturation kinetic model of Michaelis-Menten for enzymatic systems to explain the diminishing increase in milk production with an increase in the concentrate supply.

There was a substantial weight loss, when silage alone was fed only with mineral mixture. In the treatments with concentrate supplementation, there was a high live weight gain, however, without difference between them (Table 5). It can be suggested that, for the HP and LP treatments, for animals which presented live weight gain in this phase of the lactation, and then positive energy balance, the reproductive efficiency would not be negatively affected.

An economic analysis was performed, considering the prices of inputs and selling price of products in the northeast of the Minas Gerais State. Milk prices already include the award for surplus fat. In the period of the experiment, the Dollar was quoted at $\mathrm{R} \$ 2.39$. The cost per ton of sugarcane and corn silage were respectively $\mathrm{R} \$ 30.00$ and $\mathrm{R} \$ 60.00$, while the price of the sign for live cattle was $\mathrm{R} \$ 3.73 \mathrm{~kg}^{-1}$.

The feeding costs presented a linear increase with the increase in the concentrate supplementation level (Table 6). With the increase of milk production, the income increased when the cows were supplemented with concentrates. The economic analysis, considering the milk price of $\mathrm{R} \$ 0.60$, showed that only the HP treatment presented better profitability than the control. The LP treatment would only be profitable, when compared to the control, if the milk rate reached $\mathrm{R} \$ 0.77 \mathrm{~kg}^{-1}$.

The daily economy with the use of HP ration reached $\mathrm{R} \$ 0.77 \mathrm{cow}^{-1} \mathrm{day}^{-1}$. Considering the average milk production of $13.0 \mathrm{~kg} \mathrm{day}^{-1}$, this value means an economy of $\mathrm{R} \$ 0.06$ cents $\mathrm{kg}^{-1}$ of produced milk.

\section{CONCLUSION}

Concentrate for dairy cows of average yield receiving sorghum silage must contain high crude protein and mineral contents being supplied at the ratio of $1.0 \mathrm{~kg}$ per each $5.0 \mathrm{~kg}$ of milk. The response in milk production per $\mathrm{kg}$ of concentrate is higher for lower amounts amounts of concentrate with high level of protein and minerals, allowing a reduction in the production costs.

\section{REFERENCES}

AGRICULTURE AND FOOD RESEARCH COUNCIL (AFRC). Energy and protein requirements of ruminants. Wallingford: CAB International, 1993.

BARGO, F. et al. Production and digestion of supplemented dairy cows on pasture. Journal of Dairy Science, Champaign, v. 86, n. 1, p. 1-42, 2003.

FONTANELI, R. S.; PRATES, E. R.; PATIÑO, H. O. Suplementação da silagem de sorgo com diferentes fontes de proteína. In: REUNIÃO ANUAL DA SOCIEDADE BRASILEIRA DE ZOOTECNIA, 33., 1996, Fortaleza. Anais... Fortaleza: SBZ, 1996. p. 382-383.

FREITAS, J. A. et al. Predição e validação do desempenho de vacas de leite nas condições brasileiras. Archivos Latinoamericanos de Produccion Animal, Maracaibo, v. 14, n. 4, p. 128-134, 2006.

LANA, R. P. Nutrição e alimentação animal (mitos e realidades). Visconde do Rio Branco: Suprema Gráfica Ltda., 2005.

LANA, R. P. Uso racional de recursos naturais nãorenováveis: aspectos biológicos, econômicos e ambientais. Revista Brasileira de Zootecnia, Viçosa, v. 38, n. 1, p. 330340, 2009.

LANA, R. P. et al. Application of lineweaver-Burk data transformation to explain animal and plant performance 
as a function of nutrient supply. Livestock Production Science, Washington, DC, v. 98, n. 3, p. 219-224, 2005.

MACEDO, C. H. O. et al. Perfil fermentativo e composição bromatológica de silagens de sorgo em função da adubação nitrogenada. Revista Brasileira de Saúde e Produção Animal, Salvador, v. 13, n. 2, p. 371-382, 2012.

MARTIN, L. C. et al. Effect of level and form of supplemental energy and nitrogen on utilization of low quality roughages by sheep. Journal of Animal Science, Champaign, v. 53, n. 2, p. 479-488, 1981.

MERTENS, D. R. Regulation of forage intake. In: FAHEY, G. C. (Ed.). Forage quality, evaluation, and utilization. Madison: American Society of Agronomy, 1994. p. 450493.

MOORE, J. E. et al. Associative effects: are they real (?) and account for them in ration formulation. In: CORNELL NUTRITION CONFERENCE FOR FEED MANUFACTURERS, 1997, Ithaca. Proceedings... Ithaca: Cornell University, 1997. p. 1-10.

MOTA, M. F. et al. Parâmetros ruminais de vacas leiteiras mantidas em pastagem tropical. Archivos de Zootecnia, Córdoba, v. 59, n. 226, p. 217-224, 2010.

NATIONAL RESEARCH COUNCIL (NRC). Nutrient requirements of dairy cattle. 7th ed. Washington, DC: National Academy Press, 2001.

OLIVEIRA, T. S.; LANA, R. P.; GUIMARÃES, G. Crescimento animal e produção de leite em função do suprimento de nutrientes seguem o modelo de saturação cinética de Michaelis-Menten. Revista Brasileira de Agropecuária Sustentável, Viçosa, v. 1, n. 2, p. 91-99, 2011.

PIMENTEL, J. J. O. et al. Efeito da suplementação proteica no valor nutritivo de silagens de milho e de sorgo. Revista Brasileira de Zootecnia, Viçosa, v. 27, n. 5, p. 1042-1049, 1998.
PIMENTEL, J. J. O. et al. Teores de proteína bruta no concentrado e níveis de suplementação para vacas leiteiras em pastagens de capim-braquiária cv. Marandu no período da seca. Revista Brasileira de Zootecnia, Viçosa, v. 40, n. 2, p. 418-425, 2011.

SILVA, C. V. et al. Consumo, digestibilidade aparente dos nutrientes e desempenho de vacas leiteiras em pastejo com dietas com diversos níveis de concentrado e proteína bruta. Revista Brasileira de Zootecnia, Viçosa, v. 38, n. 7, p. 1372-1380, 2009.

SILVA, D. J.; QUEIROZ, A. C. Análise de alimentos: métodos químicos e biológicos. 3. ed. Viçosa: UFV, 2002.

SKLAN, D. et al. Fatty acids, calcium soaps of fatty acids and cottonseeds fed to high yielding cows. Journal of Dairy Science, Champaign, v. 75, n. 2, p. 2463-2472, 1992.

SNIFFEN, C. J. et al. A net carbohydrate and protein system for evaluating cattle diets: II. Carbohydrate and protein availability. Journal of Animal Science, Champaign, v. 70, n. 11, p. 3562-3577, 1992.

SOUZA, V. G. et al. Valor nutritivo de silagens de sorgo. Revista Brasileira de Zootecnia, Viçosa, v. 32, n. 3, p. 753759, 2003.

TEIXEIRA, R. M. A. et al. Concentrate and crude protein levels in diets for dairy Gyr lineage cows grazing elephantgrass during the rainy season. Revista Brasileira de Zootecnia, Viçosa, v. 40, n. 6, p. 1347-1355, 2011.

VALADARES FILHO, S. C. et al. Tabelas brasileiras de composição de alimentos para bovinos. 2. ed. Visconde do Rio Branco: Suprema Gráfica Ltda., 2006.

VILELA, D. et al. Desempenho de vacas da raça Holandesa em pastagem de coast-cross. Revista Brasileira de Zootecnia, Viçosa, v. 35, n. 2, p. 555-561, 2006. 